\title{
Improving Students' Writing Skill on Descriptive Text by Estafet Strategy of The Eleventh Year Students of Sma 4 Palopo
}

\author{
Dewi Furwana \\ Institut Agama Islam Negeri Palopo \\ Andi Tenrisanna Syam \\ Institut Agama Islam Negeri Palopo
}

Received : 3 April 2017; Accepted : 29 May 2019

URL : http://ejournal.iainpalopo.ac.id/index.php/ideas

\begin{abstract}
The objective of the research was to find out whether estafet strategy is effective to improve students' writing skill on descriptive text of the eleventh year students' of SMAN 4 Palopo. This research usedquasi experimental.The population of this research was the eleventh grade students of SMAN 4 Palopo. The number of population was 50 students. The sample were class XI PS 1 consisted of 25 students as experimental group and class XI PS 2 consisted of 25 students as control class. The sampling technique in this research was purposive sampling. The instrument of the research was writing test. The writers gave pretest and posttest to the students. The result showed that the students ' mean score of posttest in experimental group was 90.44 and pretest was 65.96 . The mean score of posttest was higher than the mean score of pretest $(90.44>65.96)$. While the mean score of posttest in control class was 75.76 and the mean score of pretest was 60.52. The mean score of posttest was higher than the mean score of pretest $(75.76>60.52)$. The result of statistical analysis the experimental group for level of significance 0.05 with degree of freedom $(\mathrm{df})=24$; the probability value was smaller than $\alpha 0.00<0.5$ and the result of statistical analysis the control class in which the probability value was lower than $\alpha .0 .00>0.05$. As a result, there was a significant difference in writing achievement between the students who are taught by using estafet strategy and those who are taught by non-using estafet strategy. Based on the result of this research, the writers concluded that estafet strategy upgrades the students' writing.
\end{abstract}

Key words: Teaching Writing, Descriptive Text, Estafet Strategy Introduction

Writing is one of the language skills that should be taught besides the other skills. Writing is regarded as a productive skill. It aims at assisting students in expressing their idea written. The experts believe that writing is as an important skill in setting. It helps learners to acquire English language because the activity stimulates thinking and facilitate them to develop some language skills simultaneously. According to Bello (1997), writing as a productive language skill, plays an essential role in promoting 
Dewi Furwana \& Andi Tenrisanna Syam :

Improving Students' Writing Skill on Descriptive Text by Estafet Strategy of the Eleventh Year Students of SMA 4 Palopo

language acquisition as learners experiment with words, sentence, and large chunks of writing to communicate their ideas effectively the grammar and vocabulary they learn in class.

There are four language skills taught in senior high school namely reading, listening, writing, and speaking. Here, the writers emphasizes on writing skill especially how to write descriptive text with good grammar and good organization or form writing descriptive text aims at giving vivid detail of how something or someone looks and a descriptive text also tells the readers what the thing is, or what the thing does. Writing is as productive skill that quite important in developing students' competence of senior high school.

Descriptive text is one type of the texts in Senior High School which is difficult enough to be learned by the students, although the students can use simple present and adjective clause in writing descriptive text. In learning descriptive text, students may have difficulties in learning it. Students may be confused what to write although they know the topic which has been given by the teacher. They are confused to write their idea about the topic.

The students also have to know about the structure of the English writing and the choice of words that are used in the writing. The students as academic writers have to know the process of the organization of writing. The students should be able to describe the organization and forms from a paper. Then, the student should be creative in using the technique of writing. They should know and understand to start writing, find several ideas, develop their ideas into paragraph, revise their writing and make the final writing as well as possible, (Rochwati, 2007).

Based on the observation and interview done by the writers on 4 March 2017 to the English teacher in Senior High School 4 Palopo, learning process conducted in Senior High School 4 Palopo i.e., learning is centered on the teacher. Students are less active in the following learning, therefore, students just listened and noted what the teacher has explained. The problem faced by students among other deals with difficulty reflect on the idea on the paper, the language used was still not good; students were not interested in learning descriptive text. Sometimes students feel bored writing a long text. Based on the result of an interview with some students, teacher did not use specific learning strategy that clear. In learning process teacher just gave an explanation about the descriptive text material and students just noted material that has been taught. Discussion of the group rarely done when learning interaction occurred between the students themselves and the teacher.

The writers felt compelled to solve the problems encountered in the learning process, as well as lower write as skill of the eleventh year students of SMAN 4 Palopoin writing descriptive text. And the writers found a solution that is through the process of teaching and learning writing because the same students' felt bored in a long text. The writers used estafet strategy because this strategy can make students active and enjoy so that the learning process better. Estafet strategy is cooperation between students with each other in the end student can create a text chain. In this term, estafet 
writing is one of the teaching techniques that become a source for the teacher to solve student's problems to learn writing. The use of these teaching techniques is able to give interactive teaching learning situation in which there is active interaction between teacher-students and among students. Estafet writing is a kind of teaching technique used by teacher to help the students participate actively by expressing one's idea after another continuously based on the topic given.

In addition, application of more methods effective in estafet writing for literary writing learning because students' are more motivated to learn in groups rather than individually studied. Estafet strategy is included one of the strategies of active learning or learning by doing that aims to make the Students' associate learning as an enjoyable activity. ${ }^{1}$

Application of the estafet strategy is one means to raise the motivation of learners. This can occur due to the application of appropriate strategy enabling the learning process not only runs one direction or simply dominated by the teacher with the lecture strategy. Reasons for the selection method of writing a serial for is a learning strategy that requires learners to think a high level based on the problems presented significantly. Method

This research used quasi-experimental research method. It involved two group of students with pretest and posttest design. Quasi-experimental methods that involved the creation of a comparison group are most often used when it is not possible to randomize individuals to treatment. In this research, the writers took the students of SMA Negeri 4 Palopo which had eight classes and there were25 students for each classes. So, there were 200 students. The writers took two classes as her sample; they had 50 students for each group in academic year 2018/2019. The sampling technique was purposive sampling. The writers chose purposive sampling because students' were still lack of writing ability and the students were believed can be a representative population. Since the reseacher needed many data and information, the instrument of the research was written test. Written test consisted of three numbers. The test was done in two sections: pretest and posttest. The pretest and posttest were evaluated. According to a criterion - referenced score sheet. The categories are: content, organization, vocabulary, language use, and mechanics.

\section{Results}

\section{The Mean Score and Standard Deviation of Students` Pretest and Posttest}

The result of the students ' pretest and posttest of experimental group is indicated by the mean score and standard deviation. The analysis of the mean score meant to know if there was a difference between the students' score in pretest and posttest of experimental group.

Table 1. The Mean Score and Standard Deviation of Students` Pretest and Posttest

${ }^{1}$ Syatariah, S , Menu qlis Berantai Sebagai Metode Inovatif, (Pekanbaru: CPI Rumbai 2009) p.41-42 
Dewi Furwana \& Andi Tenrisanna Syam :

Improving Students' Writing Skill on Descriptive Text by Estafet Strategy of the

Eleventh Year Students of SMA 4 Palopo

Descriptive Statistics

\begin{tabular}{|l|rr|r|r|r|}
\hline & $\mathrm{N}$ & \multicolumn{1}{|c|}{ Minimum Maximum } & Mean Std. Deviation \\
\hline Pre est & 25 & 50.00 & 80.00 & 65.9600 & 7.28858 \\
Posttest & 25 & 70.00 & 97.00 & 90.4400 & 7.28629 \\
Val d N (listwise) & 25 & & & & \\
\hline
\end{tabular}

Table 1 showed that there was a difference between the mean score of pretest and posttest in the experimental group. The mean score of posttest was higher than the mean score of pretest $(90.44>65.96)$. It means that there was an improvement after giving the treatment by using estafet strategy. The standard deviation of posttest was lower than the standard deviation of pretest $(7.286<7.288)$. It means that the scores range of posttest was closer than the score range of pretest to the mean score.

\section{The Calculation of t-test Pretest and Posttest}

The data showed in Table 2.below indicates the students' score of experimental group before conducting the treatment (pretest) and after the treatment (posttest).

Table 2. The Paired Samples Test of Pretest and Posttest

\section{Paired Samples Test}

\begin{tabular}{|c|c|c|c|c|c|c|c|c|}
\hline & \multicolumn{5}{|c|}{ Paired Differences } & \multirow[b]{4}{*}{$\mathrm{t}$} & & \multirow{4}{*}{$\begin{array}{l}\text { g. }(2- \\
\text { tailed })\end{array}$} \\
\hline & \multirow[b]{3}{*}{ Mean } & \multirow{3}{*}{$\begin{array}{l}\text { Std. } \\
\text { Deviafitc } \\
\text { on }\end{array}$} & \multirow{2}{*}{\multicolumn{3}{|c|}{$\begin{array}{c}95 \% \text { Confidence Interval } \\
\text { of the Difference }\end{array}$}} & & & \\
\hline & & & & & & & & \\
\hline & & & Mean & Lower & Upper & & df & \\
\hline Pretest & & & & & & & & \\
\hline $\begin{array}{l}\text { Posttes } \\
\mathrm{t}\end{array}$ & 24.48000 & 8.31725 & 1.66345 & -27.91319 & -21.04681 & -14.716 & $5 \quad 24$ & .000 \\
\hline
\end{tabular}

Table 2 indicated that the statistical hypothesis is based on statistic test of pretest and posttest in probability value (significant 2-tailed), probability value is lower than alpha $(0.00<0.05)$. It means that there was a statistically significant difference between students' score in pretest and posttest of experimental group giving treatment by using estafet strategy upgrade students' writing of experimental group.

\section{The Mean Score and Standard Deviation of Students` Pretest and Posttest in Control Group}

The result of the students' pretest and students' posttest of controlclass was indicated by the mean scoreand standard deviation. The analysis of the mean score was meant to know if there was a difference between the students' score in pretest and posttest of control class. The standard deviation was needed to know how closer the scores to the mean score.

Table 3. The Mean Score and Standard Deviation of Students' Pretest and Posttest

Descriptive Statistics 


\begin{tabular}{|l|rr|r|r|r|}
\hline & $\mathrm{N}$ & Minimum Maximum & Mean Std. Deviation \\
\hline Pre est & 25 & 50.00 & 75.00 & 60.5200 & 6.72756 \\
Posttest & 25 & 65.00 & 86.00 & 75.7600 & 7.06682 \\
Val d N (listwise) & 25 & & & & \\
\hline
\end{tabular}

Table 3 showed that the mean score of posttest was higher than the mean score of pretest in control class $(86.00>75.00)$ and the standard deviation in posttest is higher than the standard deviation of pretest $(7.06<6.72)$. It means that there was improvement of the students' score in control.

\section{The Paired Sample Test}

The data showed in the Table 4 below indicates the students' score of control class before conducting the treatment (pretest) and after the treatment (posttest).

Table 4. The Paired Samples Test of Pretest and Posttest

Paired Samples Test

\begin{tabular}{|c|c|c|c|c|c|c|c|}
\hline & \multicolumn{4}{|c|}{ Paired Differences } & & & \multirow{3}{*}{$\begin{array}{c}\text { iig. (2- } \\
\text { tailed } \\
\text { ) }\end{array}$} \\
\hline & \multirow[b]{2}{*}{ Mean } & \multirow{2}{*}{$\begin{array}{l}\text { Std. } \\
\text { DeviatStc } \\
\mathrm{n}\end{array}$} & \multirow{2}{*}{$\begin{array}{l}9 \\
\text { Error } \\
\text { Mean I }\end{array}$} & $\begin{array}{c}\% \text { Confidence } \\
\text { Interval of the } \\
\text { Difference } \\
\end{array}$ & \multirow[b]{2}{*}{$\mathrm{T}$} & \multirow{2}{*}{ Df } & \\
\hline & & & & fower Upper & & & \\
\hline $\begin{array}{l}\text { Pretest } \\
\text { posttest }\end{array}$ & 15.24000 & 7.79573 & .55915 & $8.4579-2 \mid 02208$ & -9.775 & 24 & .000 \\
\hline
\end{tabular}

Table 4 indicated that probability value was higher than alpha $(.000>0.05)$. It means that there was no statistically significant improvement of students' score of control class after giving the treatment by using non-estafet strategy.

\section{The Mean Score and Standard Deviation of Students' Pretest}

Before the treatment conducted both of the experimental and control class were given pretest to know the students achievement on writing knowledge. The purpose of the test was to find out whether both experimental and control class were in the same level or not. The standard deviation was meant to know how close the scores to the mean score.

Table 5. The Mean Score and Standard Deviation of Students' Pretest

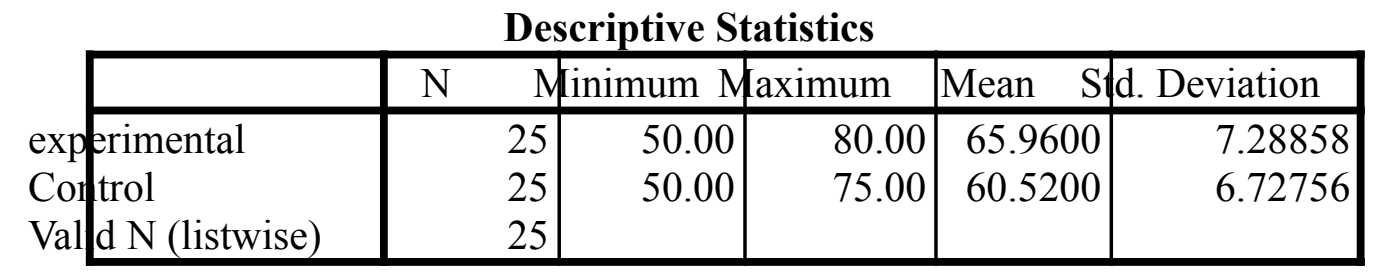

Table 5 above showed that the mean score of students' pretest of experimental group was 65.96 and control class was 60.52 . Based on the Table 5 shown above, it was 
Dewi Furwana \& Andi Tenrisanna Syam :

Improving Students' Writing Skill on Descriptive Text by Estafet Strategy of the Eleventh Year Students of SMA 4 Palopo

concluded that the students' mean score of experimental group was statistically the same with control class.

\section{The Calculation of t-test Pretest}

The data showed in the Table 6 below indicates the achievement of experimental and control class before giving the treatment.

Table 6. The Paired Samples Test of Pretest

Paired Samples Test

\begin{tabular}{|c|c|c|c|c|c|c|c|c|}
\hline & \multicolumn{5}{|c|}{ Paired Differences } & \multirow{3}{*}{$\mathrm{T} \quad \mathrm{d}$} & \multirow{3}{*}{\multicolumn{2}{|c|}{$\begin{array}{c}\text { Sifg. }(2- \\
\text { tailed } \\
\text { ( }\end{array}$}} \\
\hline & \multirow[b]{2}{*}{ Mean } & \multirow{2}{*}{$\begin{array}{l}\text { Std. } \\
\text { Deviafit } \\
\text { on }\end{array}$} & \multirow{2}{*}{$\begin{array}{l}\text { Error } \\
\text { Mean }\end{array}$} & \multicolumn{2}{|c|}{$\begin{array}{c}\$ 5 \% \text { Confidence } \\
\text { Interval of the } \\
\text { Difference }\end{array}$} & & & \\
\hline & & & & Lower & Upper & & & \\
\hline $\begin{array}{c}\text { Experimental - } \\
\text { Control }\end{array}$ & 5.44000 & 9.97948 & 1.99590 & 1.32067 & 9.55933 & 2.726 & 24 & 012 \\
\hline
\end{tabular}

Based on the statistics test of pretest in probability value (significant 2-tailed), probability value is higher than alpha $(0.12>0.05)$. It means that there was no a statistically significant difference between the average scores of the students' pretest in both experimental and control class. In other words, the students' score of both groups before conducting the treatments was almost the same.

\section{The Mean Score and Standard Deviation of Students' Posttest}

In this section, the writerss present the difference of the students' score after treatment of experimental group and control class. The result of posttest is shown in table below:

Table 7.The Mean Score and Standard Deviation of Students' Posttest

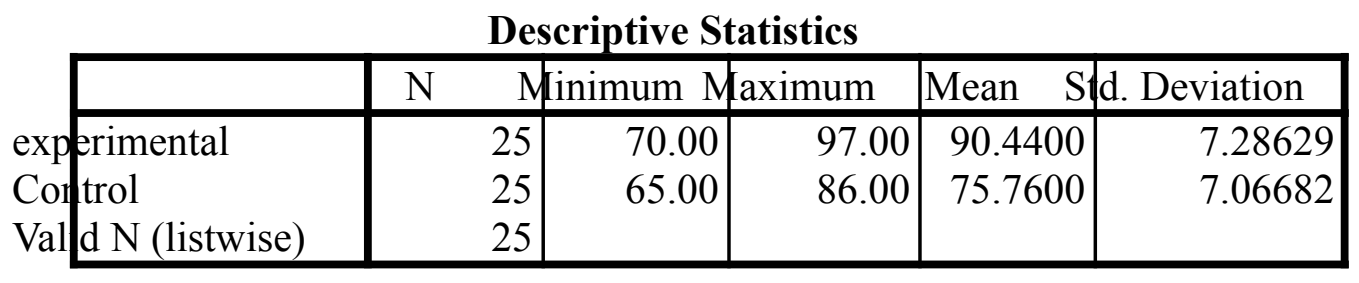

Table 7 showed that the mean scores of both experimental and control class were different after treatment. The mean score of experimental group was higher than control class $(90.44>75.76)$ and the standard deviation for experimental group was 7.28 and control class was 7.06 .

It showed that after giving the treatment, the result of experimental group on the mean score is higher than the control class. It proves that estafet strategy upgrades 
students' writing rather than non-estafet strategy.

\section{The Paired Sample of t-test Posttest}

The data were showed in the Table 8 below indicated the achievement of experimental and control class after the treatment.

Table 8. The Paired Samples Test Posttest

Paired Samples Test

\begin{tabular}{|c|c|c|c|c|c|c|c|c|}
\hline & \multicolumn{5}{|c|}{ Paired Differences } & \multirow{3}{*}{$\mathrm{T}$} & \multirow{3}{*}{ Si } & \multirow{3}{*}{$\begin{array}{c}\text { \$. }(2- \\
\text { taile } \\
\text { d) }\end{array}$} \\
\hline & \multirow[b]{2}{*}{ Mean } & \multirow{2}{*}{\begin{tabular}{|} 
Std. \\
Deviaft \\
on
\end{tabular}} & \multirow{2}{*}{$\begin{array}{l}9 \\
\text { A. Error } \\
\text { Mean I }\end{array}$} & \multicolumn{2}{|c|}{$\begin{array}{c}\% \text { Confidence } \\
\text { Interval of the } \\
\text { Difference } \\
\end{array}$} & & & \\
\hline & & & & ower & Upper & & & \\
\hline $\begin{array}{c}\text { Experimental } \\
\text { Control }\end{array}$ & 14.68000 & 8.98944 & 1.79789 & p.96934 & 8.39066 & 8.165 & 24 & 000 \\
\hline
\end{tabular}

Table 8 above indicated that the statistical hypothesis is based on statistics test in Probability value (significant 2 tailed), the Probability value was lower than alpha $(0.00<0.05)$. It means that $\mathrm{H}_{1}$ was accepted and $\mathrm{H}_{0}$ was rejected. It was concluded that after giving the treatment to the both groups, using estafet strategy in experimental group and non-estafet strategy in control class, the students' score of both groups was statistically different. It indicated that estafet strategy is more effective rather than nonestafet strategy in upgrading students`writing.

There are five items the writers analyze of writing assessment namely content, organization, vocabulary, language use, and mechanics. Students A in posttest got average to good classification in component content, organization component got average to good classification, vocabulary component got average to good classification, language use component got fair to poor classification and mechanics got excellent to very good classification. Student B in posttest content got excellent to very good classification, organization got excellent to very good classification, vocabulary got excellent to very good classification, language use got excellent to very good classification, and mechanics got excellent to very good classification. Students $\mathrm{C}$ in posttest student $\mathrm{C}$ content got fair to poor classification, organization got excellent to very good classification, vocabulary got excellent to very good classification, language use got fair to poor classification and mechanics got excellent to very good classification.

In experimental group, the mean score of posttest was higher than the mean score of pretest $(90.44>65.96)$ and the difference was statistically significant because of the $t$ test of posttest where probability value was lower than alpha $(0.00<0.05)$. While in control class, the mean score of posttest was also higher than the mean score of pretest $(75.76>60.52)$ but the difference was not statistically significant because probability value was lower than alpha $(.000<0.05)$. It was also strengthen by comparing the mean 
Dewi Furwana \& Andi Tenrisanna Syam :

Improving Students' Writing Skill on Descriptive Text by Estafet Strategy of the Eleventh Year Students of SMA 4 Palopo

score of posttest of both groups and then by calculating t-test of posttest. The mean score of students' posttest in experimental was 90.44 . While the mean score of students' posttest in control class was 75.76. The t-test of the posttest shown that there was a significant difference where probability value was lower than alpha $(0.00<0.05)$. Thus, if both strategies were compared in the implementation of teaching writing, the estafet strategy was better than non-estafet strategy

Based on the students' score in pretest, both experimental and control class have the same ability before giving the treatment. Students' score of both groups in posttest are significantly difference. In experimental class, the students' posttest in terms of content components, the data showed that there are seventeen students who got 27-30 score which was classified as very good to excellent, there are five students who got 22-26 score which was classified as good average to good, there are three students who got 1721score which was classified as poor to fair, and that is not students who got 13-16 score which was classified as very poor. Organization component, the data showed that23 students who got 18-21 score which was classified as very good to excellent, there are two students who got 14-17 score which was classified as average to good, and none of them was classified as fair to poor and very poor. Vocabulary component, the data showed that 21 students who got 18-20 score which was classified as very good excellent, there are four students who got 14-17 score which was classified as average to good, and none of them was classified as fair to poor and very poor. Language Use component, the data showed that 16 students who got 22-25 score which was classified as very good to excellent, there are seven students who got 18-20 score which was classified as average to good, there are two students who got 11-17 score which was classified as poor to fair, and that is not students who got 5-10 score which was classified as very poor. And mechanics component, the data showed that 25 students who got 5 score which was classified as very good to excellent, and none of them was classified as average to good, fair to poor and very poor.

In contrast to, in control class, the students' posttest in term of content component, there the data showed is no students who got 27-30 score which was classified as very good to excellent, there are 11 students who got 22-26 score which was classified as good average to good, there are 14 students who got 17-21score which was classified as poor to fair, and that is not students who got 13-16 score which was classified as very poor.Organization component, there data showed that six students who got 18-20 score which was classified as very good to excellent, there are 19 students who got 14-17 score which was classified as average to good, and none of them was classified as fair to poor and very poor.Vocabulary component, there the data showed that 2 students who got 18-20 score which was classified as very good excellent, there are 22 students who got 14-17 score which was classified as average to good, there are 14 students who got 10-13score which was classified as poor to fair, and that is not students who got 7-9 score which was classified as very poor. Language Use component, there data showed that is no students who got $22-25$ score which was classified as very good to excellent, 
there are 13 students who got 18-21 score which was classified as average to good, there are 12 students who got 11-17 score which was classified as poor to fair, and that is not students who got 5-10 score which was classified as very poor. And mechanics, there data showed that 16 students who got 5 score which was classified as very good to excellent, there are 8 students who got 4 score which was classified as average to good, there are one students who got 3 score which was classified as poor to fair, and none of them was classified as very poor.

The result on posttest was significant difference between experimental group and control class because in experimental group the used treatment estafet strategy in teaching writing skill. This strategy can make students active and enjoy, make the learning atmosphere more fun, and student who play in learning more seriously again so that the learning process better. And control class just used conventional method. The students' score achievement taught writing by using estafet strategy is higher than non estafet strategy.

The comparison of the students' score of both groups could be supported by analyzing the result of posttest. In pretest result, no one of 25 students either experimental group or control class was classified excellent classification (Table 4.10). After giving treatments in experimental group with estafet strategy, the result of posttest were 18 students (72\%) got excellent classification, none of them was poor and very poor, and three were in fair classification, four students or $16 \%$ got good classification (Table 4.8). Otherwise, nine students got good in result of posttest in control class. Most of them were classified at fair classification (ten students or $40 \%$ ).

There are some similaries and differences between this research and the previous related research finding Mustika (2013), found that estafet strategy is an interesting technique in teaching and learning process as it made students feel fun and active in class that their writing ability is improved. Siu (2007) found that estafet writing in learning and teaching, especially teaching writing skills strongly influences the impact on students. The writers found that the use teaching focuses writing skills but in this researcher had the same using serial writing method in same serial writing method in improving students writing skills.

Putriyani (2013) found that estafet strategy help the students to get better achievement in writing descriptive text. In short, the strength of this technique can make the Students' interested and enthusiastic in writing, more focus and comprehend about the process of writing, and in the end they will understand about the elements of writing.

\section{Conclusion}

Based on the result of data analysis, researcher concluded that estafet strategy is strongly recommended as one strategy in upgrading students' writing because in teaching writing estafet strategy has great benefits that may serve a variety of learning 
Dewi Furwana \& Andi Tenrisanna Syam :

Improving Students' Writing Skill on Descriptive Text by Estafet Strategy of the Eleventh Year Students of SMA 4 Palopo

purpose. It may provide students with a systematic means to integrate their new knowledge and stimulate them to use that knowledge to interact with the text.

To the English teachers, teaching English is difficult, so to make the students interested in this subject, the teacher should use various methods and techniques in teaching writing. Teacher can choose an appropriate method and technique based on the situation. Since this research shows that estafet strategy is better than conventional technique for teaching writing, it is recommended for teacher to use estafet strategy in teaching writing. To the students, the students should be active in the teaching and learning process and do more practice in the class. The students have to improve their competence of writing with various activities individually and in groups, because writing is not only a complex skill but also very important to academic.

\section{References}

Alice, Oshima and Ann, Hogue, (1997). Introduction to Academic Writing. (Second edition. New York: Longman.

Brown, H. Douglas. (2007).Teaching by Principles: An Interactive Approach to Language Pedagogy. San Fransisco: Pearson Longman.

Cahyono, A. (2011).Pembelajaran Menulis Sastra dengan Metode Estafet Writing di SMA. Jakarta:

David, Nunan. (1989). Design Tasks For The Communicative Classroom. New York: Cambridge University Press.

Don Byrne, (1988). Teaching Writing Skills New Edition, (London and New York: Longman Publisher), P.1

Glass, Kathy Tchman (2005). Curriculum Design for Writing Instruction. California: Corwin Press.

Harmer, Jeremy (2007). How to teach English (new edition, England: Longman.

Harmer, Jeremy (2008). How to Teach Writing. England: Pearson Education Limited.

Heaton, J.B. (1998). Writing English Language Test, New York language p. 148

Mustika. (2013) The Ability of Writing Descriptive Text of the Tenth Grade Students of SMA N 2 Kudus in the Academic Year 2013/2014 Taught by Using Estafet Writing, (Undergraduate Thesis. Unpublished Kudus: Muria Kudus University). p. 22

Novia. Quasi Experimental Design and Methods. file:///C:/Users/NOVIA/Documents/New\%20folder/Downloads/QuasiExperi mental_Design_and_Methods_ENG.pdf. Accessed on 19th May 2018. 
IDEAS, Vol. 7, No. 1, June 2019

ISSN 2338-4778 (Print) ISSN 2548-4192 (Online)

Nur, Muliani Wiwik (2007) Developing writing skill through descriptive composition at the first year students of SMU NEGERI 2 Palopo. Unpublished Thesis. Palopo: STAIN Palopo.

Oxford University Press (2003). Oxford learner's Pocket Dictionary, New York p.482

Pincas. (1987). Teaching English Writing, Essential Language Teaching Series, London: The Macmillan Publisher, Ltd.

Syatariah, S, (2009). Menulis Berantai Sebagai Metode Inovatif, (Pekanbaru: CPI Rumbai) p.42

Suryabrata, Sumadi. (2012). Metodologi Penelitia. Jakarta: Jakarta Press.

Suviana, Nova Rinda. (2010) The Effect Of Teaching Writing Descriptive Text Using Estafet Writing at SMA Pekanbaru p.22

Tajuddin, Armanto. (2011). Improving Student Grammar Ability by Using Grammar Translation Method at the Tenth Year of SMAN 4 Palopo. Palopo: STAIN Palopo.

Thomson, A.J. and A. V. Martinet. (1986). A Practical English Grammar. Oxford: Oxford University Press. 